\title{
The Impact Of Non-Audit Fees Disclosures On Company Value Following The Enron Collapse
}

Marcelo Eduardo (E-mail:eduardo@mc.edu), Mississippi College

Tao Zhang (E-mail:tzhang@olemiss.edu), University of Mississippi

\begin{abstract}
Investor confidence regarding the reliability of financial statements is absolutely critical for publicly traded companies. The bankruptcy of Enron has brought to the forefront the issue of auditor independence and financial statement reliability. As a response to the criticism that the growth in consulting services by CPA firms was leading to a conflict of interest and significantly hindering auditor independence, the SEC approved new auditor independence regulations that required publicly traded firms to disclose the level of fees that were paid to their external auditor for non-audit services.
\end{abstract}

This paper investigates the impact that the Enron collapse has had on investor perceptions about auditor independence and financial statement reliability. Using data from proxy statements concerning non-audit fees paid to external auditors, we find evidence that auditor independence and therefore financial statement reliability are compromised by the provision of these non-audit services. The results indicate that in the wake of the Enron revelations, investors perceive financial statements as being less reliable and thus require an additional risk premium, which translates into lower stock prices and a loss of firm value. We also find that there is negative relationship between the extent to which firms use non-audit services and the negative abnormal returns they suffered during the Enron collapse.

\subsection{Introduction}

n November 2000, the SEC approved new auditor independence regulations that required publicly traded firms to disclose the level of fees that were paid to their external auditor for non-audit services. This requirement was part of a response to the criticism that the growth in consulting services by CPA firms was leading to a conflict of interest and significantly hindering auditor independence.

The bankruptcy of Enron and the significant extent to which its auditor-Arthur Andersen- provided consulting and internal auditing services has brought to the forefront the issue of auditor independence and financial statement reliability. Investor confidence regarding the reliability of financial statements is absolutely critical for publicly traded companies and the impact that the Enron bankruptcy and the role of its auditor have had on the perception of financial statement users is an issue of significant importance that can be empirically examined.

The purpose of this paper is to examine the reaction of the stock market to the disclosure of non-audit fees in the wake of the Enron collapse. The study will examine whether the disclosure of non-audit fees and their proportion to regular audit fees provides information to the market and results in changes in firm value. By examining the behavior of stock prices around the time that the Enron accounting irregularities took prominent place in the news, we can make inferences regarding the information content of the non-audit fee disclosures and its impact on investor perceptions about auditor independence and financial statement reliability.

Readers with comments or questions are encouraged to contact the authors via email. 
The rest of the paper is organized as follows. Section II provides the background of the SEC's auditor independence rule and develops our hypothesis. Section III describes the data and methodology we use. Section IV presents the empirical results. Section V concludes the paper.

\subsection{Background And Hypothesis}

The collapse of Enron Corp. is one of the most significant business failures of our time. The failure of the nation's fifth largest corporation and the tangled web that precipitated its collapse has dominated the headlines. The series of unsettling revelations coming from the Enron case seemingly have led investors to look skeptically at balance sheets across the economy. The Enron failure has called into question the creation and analysis of financial statements. Considering that financial statements are the foundations upon which the American investment culture has been built, finding cracks in this structure has the potential to undermine trust in the markets (Tannenbaum, 2002)

The importance of auditor independence has been a widely recognized issue by regulators and researchers (Lowe 1999; De Angelo 1981) Auditors facilitate the relationship between investors and management by assuring the reliability of financial statements. However, this relationship is built on the assumption auditor independence (Watts and Zimmerman, 1986). Auditor independence can be defined in the context of the overall audit quality along with the likelihood that the auditor will discover and report problems with the accounting reporting (DeAngelo, 1981).

The debate about auditor independence and financial statement reliability has carried renewed force as the revelations following auditing irregularities for Enron Corp. have become widely known. At the center of the debate are the efforts of auditing firms to seek alternative sources of revenue by offering various types of professional services including internal audit, risk management, and a variety of consulting services (Swanger, 2001). This has resulted in accounting firms aggressively looking to consulting services as a way to maintain growth in the face of stagnant fee revenue from their traditional services (Lowe et al, 1999, Elliot and Pallais, 1997). CPA firms have been largely successful in this pursuit as seen by the dramatic increase in the proportion of fee revenues from nonaudit services they have earned. From 1993 to 1999, the average annual growth rate from revenues from management advisory services was 26 percent compared to 9 for audit services. In a recent study, Frankel et al, (2002) examine over 4000 publicly traded companies and find that that non-audit fee comprise approximately $70 \%$ of total fee revenue and $96 \%$ of the clients purchase non-audit services.

The SEC, concerned over the rapid growth of non-audit services by external auditors has responded with Rule S7-13-00, Revision of the Commission's Auditor Independence Requirements. In the view of the SEC, a potential conflict arises from what the agency calls a "mutuality of interest" between auditor and client (Levitt, 1996). The intent of the new SEC requirement has been to show external auditors as independent in fact as well as independent in appearance given the need for the public to maintain its confidence on the reliability of the audited financial statements (Hussey, 2001).

The new rule now requires a proxy statement disclosing the total fees paid to the external auditor. These fees are to be broken into three parts:

- $\quad$ Fees for audit of annual financial statements and quarterly review,

- $\quad$ Fees for financial information systems design and implementation; and

- $\quad$ All other fees such as internal auditing and consulting.

Furthermore, the firm's audit committee must now indicate in the proxy whether it considered the impact of the nonaudit services on its auditor's independence.

In summary, to the extent that the perception of auditor independence is as important as the actuality of independence (Schutze, 1994), part of the rationale behind the new rule appears to be to let investors decide whether the other services provided by the auditor are the "tail wagging the auditing parent dog" (Barlas, 2001). 


\subsection{Non-Audit Services And Auditor Independence}

The assurance of financial statement reliability rests to a great degree on the assumption of auditor independence. Therefore, the impact that the provision of non-audit services by the external auditor has on the perception of auditor independence is critical in determining how investors perceive the financial statements of public companies. This impact can be seen in two different perspectives.

\subsection{The View Against Auditors Providing Non-Audit Services}

Essentially, critics of the increased non-audit activity by auditing firms contend that providing all of these additional services threatens auditor independence (Swanger, 2001). To the extent that these additional services represent significant cash flows, the argument is made that these future "quasi-rent" constitute an economic bond (DeAngelo, 1981; Simunic, 1984). If this is the case, auditors with an economic interest in their clients may be less likely to report breaches in the accounting system (DeAngelo, 1981). That is, external auditors may be inclined to serve the interests of the management team rather than the interest of shareholders and investors (Cheney, 1996).

There is a significant amount of literature that finds a negative impact when auditors provide management advisory services to their clients. Swanger (2001) found that the provision of consulting services by the external auditor creates a business relationship with increased fees, makes the client more valuable to the auditor and possibly clouds the auditor's judgment for fear of losing the client. A number of other studies also find that financial statement users believe independence to be compromised if the external auditor performs consulting services for the audit client (Pany and Reckers, 1983, 1984; Reckers and Stagliano 1981, Shockley, 1981). Gul (1991) notes that when fees are a significant proportion of the auditors' total revenue, third party perceptions of the auditor's ability to withstand management power is adversely affected suggesting a link between reputation and perceived independence.

In the context of investor perceptions, some studies have found that financial statement users perceive the highest degree of independence in an audit when the consulting and audit personnel were separate as opposed when they were combined (Lowe and Pany, 1995, 1996; Pany and Reckers, 1984). A more recent study suggests that companies with a high ratio of non-audit fees to total fees are more likely to meet or beat the earnings benchmarksanalysts expectations. That is, firms with less independent auditors appear to manage their earnings more than firms that have a low ratio of non-audit fees to total fees (Frankel, Johnson, Nelson, 2002).

Finally, regulatory authorities and professional boards have also weighted-in arguing against dual work. The Public Oversight Board (POB) of the American Institute of certified Public Accountants notes that the provision of non-audit services results in lower audit quality and increased likelihood that the auditor will waive earnings management attempts (Frankel, 2002).

\subsection{The View In Favor Of Auditors Providing Non-Audit Services}

The other perspective on the auditor independence debate holds that providing non-audit services does not compromise independence but actually reinforces it. A number of studies find that in performing consulting services, auditor independence is not significantly affected (Pany and Reckers, 1983, McKinley et al, 1985). Arrunada (1999) modeled the non-audit services impact on audit quality and concluded that the dual function complements the audit function and increases the audit's firm reputation. That is, economic interest would be at risk if the firm compromised its independence since any benefit from unethical conduct would be small compared to the potential loss of the quasi-rents from many clients (Lowe et al, 1999). De Angelo (1981) noted that that the potential penalty to the reputation of the firm constraints the behavior of the auditor.

Institutional factors may also play a significant role in supporting the favorable view on the provision nonaudit services. The enhanced potential legal liability carried by CPA firms that also perform consulting or internal audits for their external audit clients may enhance their perceived objectivity and independence (AICPA 1997). Auditors face large legal sanctions from poor quality audits. Aggregate claims against the big firms reached \$30 
billion in 1992 (Frankel, 2002). Ahlawat (1998) found that due to concerns over malpractice litigation, outsourced external auditors were actually more objective than in-house internal auditors.

Lowe et al (1999) examined the impact that the outsourcing of the internal audit has on financial statement user's perceptions of auditor independence. The results of his study suggest that outsourcing the internal audit does not, in itself, negatively affect perceptions of auditor independence. Moreover the implementation of separate teams to carry out the internal and external audit functions may strengthen public confidence that the external audit function is not influenced by other relationships (Sullivan, 1995).

Finally, the AICPA position has been that increased economic interest by the external auditor may actually reinforce the independence between auditor and clients (AICPA 1997). That is, the AICPA's view is that as long as the responsibility of the internal audit function remains with management and the auditor does not take on operational responsibilities, there is no conflict of interest. This view if further amplified by the AICPA hypothesis that internal audit functions may actually provide external auditors with greater understanding of the firm and thus better prepare them to discover errors or fraud (Carmichael, 1998).

\subsection{Firm Value Effect And Hypothesis}

The net equity price reaction to non-audit fee proxy disclosure can only be assessed empirically. The new SEC regulation on auditor independence represents a significant rule that allows us to examine the impact of mandatory audit fee disclosure in providing a clearer picture of auditor independence and thus financial statement reliability. Enhanced disclosure levels of auditor activities can be either beneficial or detrimental to auditor independence and therefore carry important implications about the perceptions of financial statement users.

A negative market reaction would imply that investors regard the company as being less reliable by having auditors that are not completely independent. The result of this reaction is that investors reduce their expectations of the future CF's or interpret the high fees as signaling poor management quality or some undisclosed difficulty with the company (Frankel, et al 2002). If investors perceive the financial statements to have a higher probability to be unreliable, then they will require a additional risk premium, which would translate into, lower stock prices and loss of firm value- (Simunic, 1984). Moreover, a perception of lower audit quality may result in lower stock prices as investors revise downwards the firm's earnings' stream (Teoh and Wong, 1993).

Furthermore, the collapse of Enron, because of its magnitude, the enormous amount of coverage that it received and the focus that was placed on its auditor, represents a unique opportunity to measure investors' perception to auditor independence and financial statement reliability in the context of the new proxy disclosures.

This study posits that the new mandatory reporting requirements under the new SEC rule provide meaningful information about auditor independence and therefore affect stock prices. The greater information disclosure suggests an enhanced picture of the firm and motivates the following null hypothesis:

H1: The new SEC rules providing disclosure of non-audit fees paid to the external auditor have had no impact on stock prices in the context of the Enron accounting irregularities.

\subsection{Data And Methodology}

The study will examine whether the new SEC rule requiring the disclosure of non-audit fees paid to external auditors provides information to the market by examining the stock price reaction to these disclosures in the wake of the Enron collapse. The new SEC rule requires that registrants disclose the non-audit services the auditor provided on their proxy statements filed after February 52001.

Patel (1979) posits that from an investor's perspective, information is any data whose disclosure will alter the probability distribution over future states of the utility derived from holding a portion of the firm's debt or equity. To the extent that the new SEC rule on non-audit fee disclosure provides a more meaningful picture of 
auditor independence and therefore a clearer picture of financial statement accuracy, such probability distribution will differ from a distribution that is free of this disclosure.

Given that the utility probability distribution of an investor is unobservable, it follows that we are left with an operational technique (events study methodology) in which we analyze stock returns and test for significant changes in them that can't be explained by other events. This leads us to infer that the presence of abnormal returns during the event period is due to the non-audit fees disclosures.

Frankel et al (2002) showed in a study that reviewed over 4000 proxies that a relatively small number of clients -essentially the largest corporations-account for a disproportionate amount of each of the Big Five's nonaudit fee revenue. Thus, our study focuses on these large corporations. Our initial sample consists of the top 150 U.S. firms as listed by the 2002 Fortune 500 (America's largest corporations) ranking. In order to be included in our sample, firms have to have a definitive proxy statement filed between February 5, 2001 and September 1, 2001 in the EDGAR database. Also, firms were not chosen if they had changed auditors during the year. The final sample size given these restrictions was 115 firms. Because of their size and market values, firms included in this list receive substantial scrutiny and are closely followed by a significant number of analysts.

All 115 of the firms sampled reported fees for non-audit services, on average these fees amounted to nearly $\$ 16$ million and represented about $69 \%$ of a firm's total fees. Panel A of Table 1 shows descriptive statistics of the different fees disclosed by the proxies.

\section{TABLE 1: Descriptive Statistics of Auditor Fees and CONSULTRATIO Disclosed in the Proxy Statements}

This table presents the summary statistics of auditor fees and CONSULTRATIO disclosed in the Proxy Statements. The sample includes 115 companies that filed a definitive proxy statement between February 5, 2001 and September 1, 2001 in the EDGAR database and were listed as 150 largest American corporations by Fortune. Panel A reports the descriptive statistics of auditor fees. Panel B reports the descriptive statistics of variable CONSULTRATIO. Average is the mean of estimated coefficients of dummy variables. Std is the standard deviation of estimated coefficients of dummy variables. Max is the maximum value of variables. Min is the minimum value of variables. \% of Total Fees is the ratio of each fee on the total fees.

Panel A: Descriptive Statistics of Auditor Fees

\begin{tabular}{|lccc|}
\hline Variables & Average & Std & \% of Total Fees \\
\hline Auditor Fees & $\$ 5.101$ & $\$ 5.328$ & $24 \%$ \\
IS Fees & $\$ 2.779$ & $\$ 8.814$ & $13 \%$ \\
Other Fees & $\$ 13.217$ & $\$ 17.044$ & $63 \%$ \\
\hline
\end{tabular}

Panel B: Descriptive Statistics of CONSULTRATIO

\begin{tabular}{|lcccc|}
\hline Variables & Average & Std & Max & Min \\
\hline CONSULTRATIO & $68.8 \%$ & $15.8 \%$ & $94.2 \%$ & $22 \%$ \\
\hline
\end{tabular}

Panel B of Table 1 provides summary statistics on the extent to which the firms' non-audit fees compare to their total fees paid. This ratio, which is the ratio of all non-audit services (IS Fees plus Other Fees) to the total fees paid by the corporation to its external auditor, serves as a proxy for auditor independence and is called CONSULTRATIO.

The events related to the Enron accounting scandal are identified from the Wall Street Journal Index and the Wall Street Journal. In this study, we consider two critical events: the initial disclosure of accounting 
irregularities with Enron and the investigation of Arthur Andersen by the SEC. Event 1 is considered a significant event as it is the watershed announcement concerning Enron's accounting problems and brings to the forefront issues regarding auditor effectiveness. This event represents the announcement by the firm that its financial statements were inaccurate and led to a restatement involving a $\$ 1.2$ billion equity write-off that was a front-page story in the Wall Street Journal and provided investors with the beginning point of the Enron saga. Event 2 represents the announcement of the SEC's formal investigation of Arthur Andersen. This event is significant for it represents another critical point in the debate about auditor independence. As revelations about the role that Andersen played in providing consulting services to Enron were systematically disclosed, this date marks an identifiable point in investor skepticism towards auditor independence. Table 2 briefly illustrates the two events studied.

TABLE 2: Events Relating to Enron Accounting Scandal

\begin{tabular}{|c|c|c|}
\hline Event & Disclosure Date by WSJ & Brief Description \\
\hline 1 & October 172001 & $\begin{array}{l}\text { Accounting irregularities with Enron were disclosed- } \$ 1.2 \text { billion equity } \\
\text { write-off was undertaken }\end{array}$ \\
\hline 2 & November 292001 & Arthur Andersen was put under investigation by SEC \\
\hline
\end{tabular}

The paper uses daily stock return data from the CRSP tape from January 22001 to December 31 2001. To test the robustness of our results, we choose two market benchmark indices from the CRSP tape: CRSP valueweighted NYSE/AMEX/NASDAQ Index and the S\&P 500 Index.

There are two different statistical approaches to test the impact of certain events on the security prices. One is the FFJR model proposed by Fama, Fisher, Jensen and Roll (1969) that analyzes the cumulative abnormal returns and average abnormal returns. This approach first computes the market model from an estimation period in order to calculate the predicted normal returns. The method then calculates the abnormal returns for the sample firms by subtracting their actual returns from the predicted normal returns during the event window.

The alternative methodology is Multivariate Regression Model (MVRM) first suggested by Gibbons (1980). The MVRM adds a zero-one dummy variables for multiple events into the market model, so it is popular in research testing the significance of different events on security prices. The estimated coefficient of the dummy variable represents the effect of a specific event on the security prices. In this study, we use this dummy variable approach. The regression model is the following:

$$
R_{i t}=\alpha_{i}+\beta i R_{M t}+\sum_{e=1}^{E} \gamma_{i e} D_{e t}+u_{i t}
$$

where:

$R_{i t}=\quad$ the daily returns of the stock $i$ on day $t$

$R_{M t}=$ the daily return of S\&P 500 Index or CRSP value-weighted NYSE and AMEX/NASDAQ Index on day $t$;

$\gamma_{i e}=$ the effect of the $e$ th event on the price of stock $i$;

$D_{e t}=$ dummy variables that equal one during the three-day event window (the disclosure date by WSJ and before and after one trading day) and zero otherwise;

$E=\quad$ number of events studied (equal to two in this study).

Following Espahbodi et al (1995), we set the dummy variables to one during the disclosure date by WSJ as well as one trading day before and after, and to zero otherwise. The purpose of selecting three-day event window is to account for the unknown exact timing of information release. The model is estimated over the period from January 2, 2001 to December 31, 2001. 
When we assume that the coefficients in the equation (1) are different for each company, we have the Seemingly Unrelated Regression model (SUR). Following Greene (2000), the FGLS regression is used to account for the unknown covariance matrix of the disturbance. As the first step of FGLS regression, we obtain the OLS residuals to estimate the consistent cross-sectional covariance matrix.

The first null hypothesis is that the average abnormal return during each of event period equals zero:

$$
H_{0}: \quad \overline{\gamma_{i e}}=0
$$

where $i$ is the number of companies in the sample, and $e$ is the $e$ th events in the study. $H_{0}$ is similar to the analysis of average abnormal return in Fama et al's model. Besides, we consider two joint linear hypotheses:

$$
\begin{aligned}
& H_{1}: \quad \gamma_{i e}=0 \quad \forall i, e \\
& H_{2}: \quad \gamma_{i e}=0 \quad \forall i
\end{aligned}
$$

where $i$ is the number of companies in the sample, and $e$ is the eth events in the study. $H_{1}$ tests whether both events have a significant impact on the stock prices, while $H_{2}$ tests the impact from only one of the events. Binder (1985) argued that the main advantage of MVRM over Fama et al's market model approach is that MVRM can easily handle the joint linear hypothesis test because MVRM explicitly incorporate cross-sectional correlations in the parameter estimation and hypothesis testing.

Our study will also measure the impact on firm value of the non-audit service fees disclosure by focusing on the magnitude of these fees compared to the total audit feed paid by each firm. In order to do this, a proxy for the extent to which the firm engages its auditors for non-audit services is computed. This proxy is the ratio of non-audit fees (the sum of IS and other fees) to total audit fees and we call it CONSULTRATIO. The ratio of these two fees has been used as a proxy for auditor independence before (Firth 1997, Barkness and Simnett 1994).

Given that we posit that stock prices will react to the information disclosure, we use the CONSULTRATIO variable as a proxy for the degree to which the market views auditors as being independent and thus views the financial statements as being reliable. We test the impact that the level of non-audit fees has had on the abnormal returns by estimating the following regression:

$$
D_{e}=\alpha_{e}+\beta_{e} *(\text { CONSULTRATIO })+\varepsilon_{e}
$$

where:

$D_{e}=$ estimated coefficient of the dummy variable (abnormal returns) from equation (1)

CONSULTRATIO = the ratio of all non-audit services (IS fees plus Other fees) to the total fees paid by the firm to its external auditor

The estimate of $\beta_{e}$ represents the effect of non-audit fees on investor reaction to each of the events. To the extent that the market views high levels of non-audit fees as hindering auditor independence and financial statement reliability, we would expect the estimate of $\beta_{e}$ to be negative $\mathrm{i}^{\mathrm{i}}$. 


\subsection{Results}

Table 3 presents the excess returns resulting from equation (1) for the period from January 22001 to December 31 2001. The estimated coefficients of the dummy variables measure the impact on the stock prices of different events associated with the Enron revelations. Panel A and B use the CRSP value-weighted NYSE/AMEX/NASDAQ index and SP500 Index respectively. The results indicate the presence of significant negative abnormal returns from Event 1, e.g. the average abnormal return is -0.00274 when compared to the CRSP value-weighted NYSE/AMEX/NASDAQ Index with significance at the level of $1 \%$. The average abnormal return is -0.00249 when compared to the S\&P500 Index with significance at the level of 5\%.

On the other hand, the results show that Event 2 has a relatively smaller impact on firm value: the average abnormal return is only significantly different from zero at the $10 \%$ level when compared to the CRSP valueweighted NYSE/AMEX/NASDAQ Index.

As Panel $\mathrm{C}$ of Table 3 shows, the F-statistics of the estimated coefficients for dummy variables reject the null hypothesis that all the abnormal returns from all events are not significantly different from zero. Panel D reports the testing results of null hypothesis $\mathrm{H}_{2}$. The $\mathrm{F}$ statistics show that the abnormal returns from either of two events are significantly different from zero at the level of $1 \%$. These findings suggest the presence of significantly negative abnormal returns accompanying the announcement of Enron accounting irregularities. The results provide evidence consistent with the argument that investors reduced their valuations as a compensation for the perceived reduction in audit quality. These results may also indicate negative perceptions by investors concerning the quality of the expected future cash flows.

\section{TABLE 3: Estimation of Dummy Variables in MVRM/SUR Model}

Summary statistics for the estimation of dummy variables in the MVRM/SUR model from January 22001 to December 312001. There are total 115 companies and 248 trading days. Panel A uses the CRSP value-weighted NYSE/AMEX/NASDAQ Index as market benchmark. Panel B uses the SP500 Index as market benchmark. Event 1 and 2 are the events described in Table 2. Average is the mean of estimated coefficients of dummy variables. Std is the standard deviation of estimated coefficients of dummy variables. Max is the maximum value of estimated coefficients of dummy variables. Min is the minimum value of estimated coefficients of dummy variables. Median is the median value of estimated coefficients of dummy variables. t-statistics of mean of the estimated coefficients of the dummy variables is in the parenthesis. Panel C and D report the test of the two jointly linear hypothesis of $H_{1}$ and $H_{2}$.

Panel A: CRSP value-weighted NYSE/AMEX/NASDAQ Index as market benchmark

\begin{tabular}{|cccccc|}
\hline Event & Average & Std & Max & Min & Median \\
\hline 1 & -0.00274 & 0.012485 & 0.028746 & -0.06004 & -0.00183 \\
& $(-2.355)^{* * *}$ & & & & 0.0909 \\
2 & -0.0017 & 0.013338 & 0.027732 & 0.00194 \\
& $(-1.365)^{*}$ & & & & \\
\hline
\end{tabular}

Panel B: SP500 Index as market benchmark

\begin{tabular}{|cccccc|}
\hline Event & Average & Std & Max & Min & Median \\
\hline 1 & -0.00249 & 0.012517 & 0.029066 & -0.05973 & -0.00165 \\
& $(-2.135)^{* *}$ & & & & \\
2 & -0.00134 & 0.013332 & 0.028472 & -0.09055 & 0.000659 \\
& $(-1.080)$ & & & \\
\hline
\end{tabular}


Panel C: Test of jointly linear hypotheses of $H_{1}$

\begin{tabular}{|ccc|}
\hline & CRSP value-weighted NYSE/AMEX/NASDAQ Index & SP500 Index \\
\hline F statistic & 1.86 & 1.85 \\
p-value & 0.0001 & 0.0001 \\
\hline
\end{tabular}

Panel D: Test of jointly linear hypotheses of $\mathrm{H}_{2}$

\begin{tabular}{|clcc|}
\hline Event & & CRSP value-weighted NYSE/AMEX/NASDAQ Index & SP500 Index \\
\hline \multirow{2}{*}{1} & F statistic & 1.97 & 1.95 \\
& p-value & 0.0001 & 0.0001 \\
& F statistic & 1.75 & 1.74 \\
& p-value & 0.0001 & 0.0001 \\
\hline
\end{tabular}

*** Significant at the $1 \%$ level based on a one-tailed t-test

** Significant at the $5 \%$ level based on a one-tailed t-test

* Significant at the $10 \%$ level based on a one-tailed t-test

Table 4 below shows the results for the regression between the abnormal returns and the ratio of consulting fees to total audit fees. The dependent variable is the dummy variable coefficients of different events, while the independent variable is the firm characteristic reflecting the independence and accuracy of financial statements -the ratio of non-audit fees over total fees paid to external auditors. Panel A reports the OLS regression of equation (5). Generally, the relationship between the coefficients of dummy variables and the ratio of non-auditing fee is negative for Event 1 with significance at the level of 5\%. But the same relationship for Event 2 is not significantly different from zero. These finding are consistent with the results found in the Table 4 where Event 2 has smaller abnormal returns than Event 1. Panel B shows that there is no evidence of significant positive and negative AR (1) and AR (2) autocorrelation among OLS residues. And Panel C indicates that OLS residues for Event 1 and 2 have few sign of heteroscedasticity. But we still report the t-statistics adjusted by heteroscedastic-consistent standard errors in Panel A.

Overall, Table 4 shows strong evidence that the abnormal returns of Event 1 are negatively related with the ratio of non-audit fee. This result suggests that investors reassessed their perceptions of auditor independence and financial statement reliability when the first big shock news from Enron took place. The subsequent official investigation of Arthur Andersen by the SEC has no impact on firm values. That is, the influence of Event 2 on the level of abnormal returns is minimal and we posit can be understood in the context of "old" news from the perspective of investors.

TABLE 4: Parameter Estimates for the Regression between Abnormal Returns And Consulting Fee Ratio

Panel A reports the OLS estimation of equation (5):

$$
D_{e}=\alpha_{e}+\beta_{e} *(\text { CONSULTRATIO })+\varepsilon_{e}
$$

Where $D_{e}$ is the estimated coefficient of dummy variable from equation (3), CONSULTRATIO is the ratio of all non-audit services (IS Fees plus Other Fees) to the total fees paid by the corporation to its external auditor. Panel B reports the Generalized Durbin-Watson statistics of autocorrelation for OLS residues for Event 1 and 2 compared to CRSP value-weighted NYSE/AMEX/NASDAQ Index and SP500 Index. Panel C reports the results of White tests for heteroscedasticity of OLS residue for Event 1 and 2 compared to CRSP value-weighted NYSE/AMEX/NASDAQ Index and SP500 Index. t-statistics calculated by the heteroscedasticity-consistent standard errors are in the parenthesis. 
Panel A: OLS regression of dummy against ratio of non-audit fee

\begin{tabular}{|ccccc|}
\hline & \multicolumn{2}{c|}{ SP500 Index } \\
\hline$\alpha_{e}$ & $\mathrm{e}=1($ Event 1$)$ & $\mathrm{e}=1$ (Event 1) & $\mathrm{e}=2$ (Event 2) \\
$\beta_{e}$ & 0.00893 & 0.00147 & 0.00916 & 0.00187 \\
& -0.01698 & -0.00461 & -0.01694 & -0.00467 \\
\hline$R^{2}$ & $(-2.34)^{* *}$ & $(-0.64)$ & $(-2.32)^{* *}$ & $(-0.65)$ \\
\hline
\end{tabular}

$* * *$ : Significant at the $1 \%$ level based on a two-tailed t-test

$* *$ : Significant at the $5 \%$ level based on a two-tailed t-test

*: Significant at the $10 \%$ level based on a two-tailed t-test

Panel B: Generalized Durbin-Watson test for AR (1) and AR (2) autocorrelation of OLS residues

\begin{tabular}{|c|c|c|c|c|c|c|c|}
\hline & & \multicolumn{3}{|c|}{ CRSP value-weighted NYSE/AMEX/NASDAQ Index } & \multicolumn{3}{|c|}{ SP500 Index } \\
\hline & Order & DW & $\begin{array}{c}\text { Positive } \\
\text { Autocorrelation P } \\
\text { value }\end{array}$ & $\begin{array}{c}\text { Negative } \\
\text { Autocorrelation } \mathrm{P} \\
\text { value }\end{array}$ & DW & $\begin{array}{c}\text { Positive } \\
\text { Autocorrelation } \\
\text { P value }\end{array}$ & $\begin{array}{c}\text { Negative } \\
\text { Autocorrelation } \\
\text { P value }\end{array}$ \\
\hline \multirow{2}{*}{ Event 1} & 1 & 2.0314 & 0.5638 & 0.4362 & 2.0295 & 0.5596 & 0.4404 \\
\hline & 2 & 1.9092 & 0.3432 & 0.6568 & 1.9086 & 0.342 & 0.658 \\
\hline \multirow{2}{*}{ Event 2} & 1 & 1.8468 & 0.2021 & 0.7979 & 1.846 & 0.201 & 0.799 \\
\hline & 2 & 1.8513 & 0.237 & 0.763 & 1.852 & 0.2381 & 0.7619 \\
\hline
\end{tabular}

Panel C: White test for heteroscedasticity of OLS residues

\begin{tabular}{|ccccc|}
\hline & \multicolumn{2}{c|}{ CRSP value-weighted NYSE/AMEX/NASDAQ Index } & \multicolumn{2}{c|}{ SP500 Index } \\
\hline & $\chi^{2}$ & P value & $\chi^{2}$ & P value \\
\hline Event 1 & 0.05 & 0.9750 & 0.06 & 0.9682 \\
Event 2 & 0.74 & 0.691 & 0.76 & 0.6825 \\
\hline
\end{tabular}

\subsection{Summary And Conclusions}

The question of whether the provision of non-audit services by the external auditor impacts investor perceptions about auditor independence and thus perceptions about financial statement reliability is a critical issue to the financial markets and the overall economy. The SEC, concerned over the rapid growth of non-audit services by external auditors enacted Rule S7-13-00 that requires a proxy statement disclosing the total fees paid to the external auditor.

Using a sample of 115 large U.S. firms, we tested the proposition that the non-audit fee disclosures have no significant effect on their stock prices. The impact on firm value was specifically tested against two important events in the Enron debacle. The first event was the initial announcement of the accounting irregularities at Enron that resulted in a $\$ 1.2$ billion dollars equity write-off. The second event involved the announcement that Enron's auditor-Arthur Andersen-was being investigated by the SEC.

The results suggest the presence of significantly negative abnormal returns for event 1 . Moreover, the extent to which the firms in the sample used non-audit services from its external auditor (a proxy for auditor independence) is negatively and significantly related to the abnormal returns for the event announcing the accounting irregularities at Enron. These results are consistent with the argument that non-audit services are detrimental to auditor independence and financial statement reliability perceptions. The relationship between auditor 
independence and abnormal returns under the announcement of the SEC investigation of Andersen are less robust and not significant. We argue that this announcement is viewed as "old" news for investors and that they have already priced the auditor independence effect during the initial announcement of accounting irregularities at Enron.

In summary, the results of the study suggest that auditor independence and therefore financial statement reliability are compromised by the provision of non-audit services by the external auditor. The results also indicate that in the wake of the Enron revelations, investors perceive financial statements as being less reliable thus require a additional risk premium, which translates into lower stock prices and a loss of firm value.

\section{References}

1. Ahlawat, S. S. 1998. "Outsourcing of the Internal Audit Function: Implications for Auditor Objectivity.” Working paper, Rutgers University.

2. American Institute of Certified Public Accountants (AICPA). 1997. Serving the Public Interest: A New Conceptual Framework for Auditor Independence, New York, NY: AICPA.

3. Arrunada, B. 1999. The Economics of Audit Quality: Private Incentives and the Regulation of Audit and Non-Audit Services. Norwell, MA: Kluwer Academic Publishers.

4. Barlas, Stephen, Jan 2001. "Corporate Audit Committee Must Gear Up." Strategic Finance, Volume 82, Issue 7, 2324.

5. $\quad$ Barkess, L., and R. Simnett. 1994. "The Provision of Other Services by Auditors: Independence and Pricing Issues." Accounting and Business Research 24: 99-108.

6. Binder, J. J., Spring 1985. "On the Use of the Multivariate Regression Model in Event Studies", Journal of Accounting Research, Vol. 23, pp. 370-383.

7. Carmichael, D. R. 1998. “A Conceptual Framework for Independence.” The CPA Journal (March): 16-23.

8. Cheney, G. 1995. "Internal Auditors Push AICPA on Outsourcing Ethics.” Accounting Today (May 20-June 2): 14,49.

9. DeAngelo, L. 1981. “Auditor Size and Audit Quality.” Journal of Accounting and Economics 3: 183-199.

10. Elliott, R. K., and D. M. Pallais. 1997. “Are You Ready for the New Assurance Services?” Journal of Accountancy (June): 47-51.

11. Espahbodi, H., P. Espahbodi, and H. Tehranian. 1995. "Equity Price Reaction to the Pronouncements Related to Accounting for Income Taxes," The Accounting Review, Volume 70 Number 4, p. 655-668.

12. Fama, E., Fisher, L., and Jensen, M. C., 1969. "The Adjustment of Stock Prices to New Information," International Economic Review, pp. 1-21.

13. Firth, M. 1997. "The Provision of Non-audit Services by Accounting Firms to their Audit Clients." Contemporary Accounting Research 14: 1-21.

14. Frankel, Richard, M. Johnson, and K. Nelson, 2002, “The Relation Between Auditors' Fees for Non-Audit Services and Earnings Quality.” Working paper, Sloan School of Business.

15. Gibbons, M. R., 1980. "Econometric Models for Testing a Class of Financial Models- An Application of the Nonlinear Multivariate Regression Model.", Ph.D. dissertation, University of Chicago.

16. Greene, W.H. 2000. Econometric Analysis, Upper Saddle River, NJ, Prentice Hall

17. Gul, E.A. 1991, "Size of Audit Fees and Perceptions of Auditors' Ability to Resist Management Pressure in Audit Conflict," ABACUS, 162-170

18. Hussey, Roger and George Lan. Jul 2001. "An Examination of Auditor Independence Issues from the Perspectives of U.K. finance directors." Journal of Business Ethics; Dordrecht ,Volume 43, Issue 2, pp. 169-178.

19. Levitt, A. 1996. Remarks given at the $24^{\text {th }}$ Annual National Conference on Current SEC Developments, Washington D. C., December 10. http://www.sec.gov/news/speeches/ spch122.txt.

20. Lowe, D. J., and K. Pany. 1995. "CPA Performance of Consulting Engagements with Audit Clients: Effect on Financial Users' Perceptions and Decisions.” Auditing: A Journal of Practice \& Theory (Fall): 35-53.

21. Lowe, D. Jordan, Marshall A. Geiger, and Kurt Pany. 1999. "The Effects of Internal Audit Outsourcing on Perceived External Auditor Independence." Auditing; Volume 18, pp. 7-26.

22. McKinley, S., K. Pany, and PM.J. Reckers. 1985. "An Examination of the Influence of CPA Firm Type, Size, and MAS provision on Loan Officer Decisions and Perceptions." Journal of Accounting Research (Autumn): 887-896.

23. Pany, K., and P.M. J. Reckers, 1983. "Auditor Independence and Non-audit Services: Director Views and their Policy Implications.” Journal of Accounting and Public Policy 2 (1): 43-62.

24. Pany, K., and P.M. J. Reckers, 1984. "Non-audit Services and Auditor Independence," Auditing: A Journal of Practice \& Theory, (Fall): 39-53.

25. Patel, James 1979. "The API and the Design of Experiments.” Journal of Accounting Research (Autumn): 529-549. 
26. Reckers, P. M. J., and A. J. Stagliano. 1981. "Non-audit Services and Perceived Independence: Some New Evidence." Auditing: A Journal of Practice \& Theory (Spring): 23-37.

27. Securities and Exchange Commission. 2000. Final Rule: Revision of the Commission's Auditor Independence Requirements. Washington, D. C.

28. Schuetze, W. P. 1994, 'A Mountain or a Molehill?' Accounting Horizons 8, 69-75.

29. Simunic, D. 1984. “Auditing, Consulting, and Auditor Independence.” Journal of Accounting Research 22: 679-702.

30. Shockley, R. A. 1981. "Perceptions of Auditors' Independence: An Empirical Analysis.” The Accounting Review (October): 785-800.

31. Sullivan, J.D. 1995, Letter of June $14^{\text {th }}$ to Herbert Finkston, Director of Professional Ethic (AICPA). Stamford, CT: Public Oversight Board.

32. Swanger, Susan L.and Eugene G. Chewning Jr. Sep 2001. “The Effect of Internal Audit Outsourcing Financial Analysts' Perceptions of External Auditor Independence.” Auditing; Sarasota, Volume 20, pp. 115-129.

33. Teoh, S. H., and T. J. Wong. 1993. "Perceived Auditor Quality and the Earnings Response Coefficient." The Accounting Review 68: 346-367.

34. Tannenbaum, Carl R. "The Auditor as Enabler." American Bankers Association. ABA Banking Journal. New York, April 2002, Volume 94, pg. 64.

35. Watts, R. L., and J. L. Zimmerman. 1986. Positive Accounting Theory. Englewood Cliffs, NJ: Prentice-Hall Inc.

\section{Endnote}

${ }^{i}$ During estimation of equation (5), we tested for autocorrelation and heteroscedasticity in the cross-sectional OLS residues. First, we use the generalized Durbin-Watson statistics to test for first- and second-order autocorrelation, then we use the White test to identify the heteroscedasticity. We also calculate the Eicker-White heteroscedasticityconsistent variance and covariance from OLS estimation to get the heteroscedasticity-adjusted $t$ statistic for the estimated coefficients. 